\title{
Editorial
}

\section{New Libraries Remain an Excellent Investment}

Building the case for constructing a new library is becoming increasingly difficult. Based on the decline in the number of people coming into libraries, the decrease in the number of reference queries, and the significant increase in the number of electronic resources acquired, decision makers are asking, "Why do we need a new library?" The argument against new libraries is further supported by the digital revolution, the popularity of storage facilities, and the emphasis on access over ownership.

The library's role on campus should be growing, not shrinking.

Unfortunately, many library users believe that everything is on the Internet. Librarians have worked diligently to improve access to electronic resources, and now we are trying to explain to users that only a small amount of the world's information resources can be accessed online. We have been quite successful in improving convenience for users but have not done well in articulating that it is necessary to visit the library for more comprehensive term papers and extensive research.

\section{Limiting Factors}

The academic libraries that continue to thrive in attendance and usage are the ones that have well-designed buildings and lively programming. Scott Carlson, writing for The Chronicle of Higher Education, denotes that limiting factors (e.g., money and the nature of the building) have a negative influence on student use of libraries. Structures that offer cramped spaces and poor lighting often drive stu- dents to more attractive parts of campus-or to the nearest coffee shop. ${ }^{1}$ Notwithstanding their excellent collections, some older universities have deplorable library facilities, especially the book stacks and reading areas. A current architectural analysis of these old, dingy, dark libraries would certainly reveal a common conclusion: These older libraries were designed without the future user thoroughly in mind.

\section{A New Joint-Use Library}

At Nova Southeastern University where I am Vice President for Information Services and University Librarian, we recently dedicated a new joint-use library with the Broward County Board of County Commissioners. With its 325,000 square feet, it is Florida's largest library. Broward County paid 50 percent of the construction costs and is contributing 40 percent toward the annual operating expenses. The building is owned and operated by Nova Southeastern University. The Broward County Library System contains the main library in Fort Lauderdale and about thirty-six branch libraries throughout the county. Except for a youth services area, the new building is seamless; that is, one cannot differentiate between public and academic resources/services. It is a high-tech facility using both wire lines and wireless technology. A "smart building" is a good description of the facility. Flexibility and future expansion for services and collections are plentiful, and the building's design engenders an "intensely human" environment.

Use of the joint-use facility has exceeded everyone's expectations. Special features that have helped to attract users 
include the group study rooms, the "connections" cafe, the electronic classrooms, and the performing arts center. Unquestionably, the new library is the signature building on campus. From its earliest concept, we agreed that this new library must be designed for the current and future user. Large exhibit areas, space for artwork, and the 500-seat state-of-the-art performing arts center establish the building as a cultural center as well as a library. The collaboration between the private university and a public library illustrates a classic case of synergy. The two entities are realizing from collective efforts what they could not achieve via individual achievements. I predict that we will witness construction of several other jointuse libraries in the near future.

\section{Expectations of Users}

During the first month's occupancy of the new joint-use library, I frequently asked users what they thought of it. They used words such as "awesome" and "unbelievable" to describe the new library. After I probed a bit further, they told me that they especially liked the group study rooms, the electronic classrooms, the wireless technology, and the convenience of services (including the food and drink in the cafe).

Functions of library space are changing; it is very important to keep the user's expectations uppermost in mind while designing a new library. The solitary student is disappearing; the study group has arrived. The modern academic library includes informal space for students to socialize. ${ }^{2}$ With the fast-expanding em- phasis on distance education, the modern library should have distance-learning capabilities. The library's role on campus should be growing, not shrinking. For example, the computer help desk could be located in close proximity to the reference desk, the student tutoring center and the career services unit could be located in the library, and numerous other student services areas may be good candidates for moving to the library. With the library open more hours per week than most other campus units, it is an ideal location for promoting one-stop shopping.

\section{Conclusion}

We should not expect to see again the enthusiasm for constructing new libraries as witnessed in the past four decades. Despite its oversimplification, the belief that "everything is going to be online" influences decision makers not to fund requests for new libraries. The digital revolution has not reduced the need for books in paper format. Questia and netLibrary are not doing as well in marketing their products as expected. In their traditional format, books will continue to be published in huge quantities. Undoubtedly, the need for libraries as physical places will continue. However, the academic library must reinvent itself. Group study, socializing, food, campus centers, cultural center, joint-use, and information commons are concepts, in addition to traditional roles, that one will find integrated with modern academic library purposes.

DONALD E. RIGGS

Editor, College $\mathcal{E}$ Research Libraries

\section{Notes}

1. Scott Carlson, "The Deserted Library," Chronicle of Higher Education 48 (Nov. 16, 2001): A35-A38.

2. Michael J. Crosbie and Damon D. Hickey, When Change Is Set in Stone: An Analysis of Seven Academic Libraries Designed by Perry Dean Rogers \& Partners (Chicago: ALA, 2001), 5. 